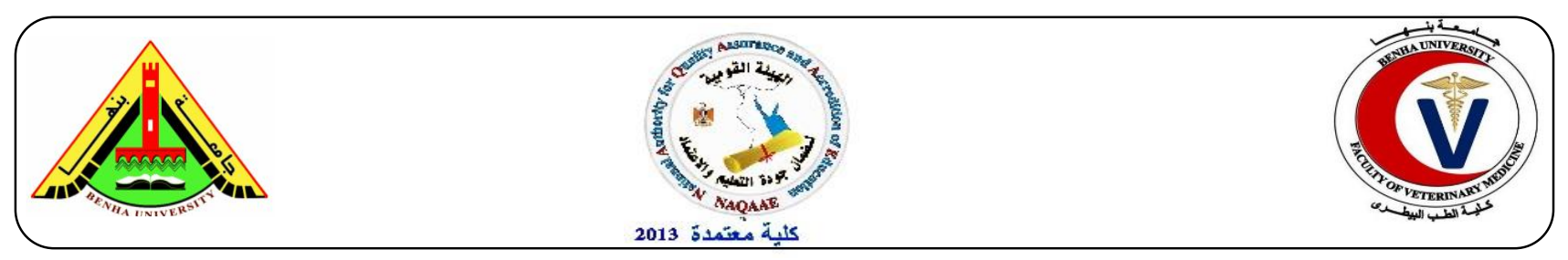

\title{
Evaluation of nitrite and sodium chloride in some locally manufactured meat products
}

Saad $^{1}$, M.S; Hassan', M.A.; Reham ${ }^{1}$, A. Amin, El- Shater'2, M.A.; Shanab ${ }^{2}$, M.S.

${ }^{1}$ Food Hygiene and Control Department, Faculty of Veterinary Medicine, Benha University.

${ }^{2}$ Animal Health Research. Institute, Dokki- Giza.

\begin{abstract}
A B S T R A C T
This study is for detection of some food additives used on manufacturing of some meat products as nitrite and sodium chloride. A total of 150 random samples of locally manufactured meat products represented by beef burger, Kofta, frankfurter, sausage and luncheon (30 of each) were collected from different markets, Egypt. The collected samples of beef burger, kofta, frankfurter and sausage were frozen and the weight of each unit was $340 \mathrm{~g}$. while, the luncheon samples were collected as slices $(250 \mathrm{~g})$. Each sample was kept in a separate plastic bag and preserved in an ice box then transferred to the laboratory without delay. The collected samples were examined to determine nitrite and sodium chloride contents. The mean values of nitrite in beef burger, kofta, frankfurter, sausage and luncheon were $46.75 \pm 2.33,52.18 \pm 2.64,59.29 \pm 3.10,67.73 \pm 3.48$ and $79.40 \pm 3.52$, respectively. Moreover the the mean values of Sodium chloride $(\%)$ in beef burger, kofta, frankfurter, sausage and luncheon were $1.91 \pm 0.28,2.89 \pm 0.41,2.75 \pm 0.32,3.07 \pm 0.37$ and $3.30 \pm 0.39$, respectively. The current study revealed the acceptable and non-acceptable meat products exposed to illegal amounts of nitrite and Sodium chloride according to ES (2005).
\end{abstract}

Keywords: Nitrite, sodium chloride, beef burger, kofta, sausage.

(http://www.bvmj.bu.edu.eg) $\quad$ (BVMJ-35(2): 188-194, 2018)

\section{INTRODUCTION}

Food additive means any substance not normally consumed as a food by itself and not normally used as a typical ingredient of the food.

Nitrates and nitrites are short names for "Sodium nitrate" and "Sodium nitrite" which are forms of salt. Common salt (Sodium chloride) has been used for thousands of years to preserve meat well before the discovery of refrigeration. Several centuries ago, nitrate and nitrite salts were recorded in salt by accident and it was soon realized these closely related ingredients helped to extend the shelf life (aka. preserve) of meat by preventing rancidity and by also controlling the growth of bacteria (Sindelar,2012).

Nitrite has several adverse effects on human health, for example, in vivo reaction between nitrite and secondary or tertiary amines producers $\mathrm{N}$-nitrosamines, which are potential carcinogens, mutagens and/or teratogens (Bories and Bories, 1995)

Sodium chloride was dissolved in water to form brine solution which retard microbial 
growth, it aids in solubility of the myosin-type protein of comminuted muscle for emulsifying in emulsion and contributes to basic taste characteristics

The excess of Sodium chloride intake above nutritional recommendation many involve harmful consequences to health such as hypertension and some cardiovascular diseases (Taormina, 2010 and Ripolles et al., 2011)

Therefore, the current study was planned out to determine the contents of Sodium nitrite and Sodium chloride in some locally manufactured meat products (Beef burger, Kofta, Frankfurter, Sausage and Luncheon) and their acceptability for human consumption with the legal limits of ES 2005.

\section{Materials and methods}

A total of 150 random samples of locally manufactured meat products represented by beef burger, kofta, frankfurter, sausage and luncheon (30 of each) were collected from different markets, Egypt. The collected samples of beef burger, kofta, frankfurter and sausage were frozen and the weight of each unit was 340 g., while, the luncheon samples were collected as slices $(250 \mathrm{~g})$.

Each sample was kept in a separate plastic bag and preserved in an ice box then transferred to the laboratory without undue delay. The collected samples were subjected to the chemical examination for evaluation of nitrite and Sodium chloride.

\subsection{Determination of nitrite (AOAC, 2016):}

Accurately, $5 \mathrm{~g}$ of prepared sample were weighed in $50 \mathrm{ml}$ beaker, then $40 \mathrm{ml} \mathrm{H}_{2} \mathrm{O}$ heated to $80^{\circ} \mathrm{C}$ were added to the sample. The mixture was mixed thoroughly with glass rod and transferred to $500 \mathrm{~mL}$ volumetric flask.

The beaker and rod were thoroughly washed with successive portions of the hot water. Further, enough hot water was added to bring volume to $300 \mathrm{ml}$, and then stand in steam bath for 2 hours with shaking. The contents were cooled to room temperature, diluted to $500 \mathrm{ml}$ with distilled water, remixed and then filtered. If turbidity remains after filtration, centrifuging will till be cleared of the solution. Moreover, $2.5 \mathrm{ml}$ sulfanilamide reagent was added to $10 \mathrm{ml}$ of the filtrate, and mixed. After 5 min, $2.5 \mathrm{ml}$ NED (N-(1-naphthyl) ethylenediamine) reagent was added, diluted to $50 \mathrm{ml}$ and mixed. Accordingly, the developed color within 15 minutes was determined at 540 $\mathrm{nm}$ against blank of $45 \mathrm{ml}$ water, $2.5 \mathrm{ml}$ sulfanilamide reagent and $2.5 \mathrm{~mL}$ NED reagent using spectrophotometer.

Nitrite present was determined by comparison with standard curve prepared as follows: 10, 20, 30, and $40 \mathrm{ml}$ nitrite working standard solutions were separately added to 50 mlvolumetric flasks and $2.5 \mathrm{ml}$ sulfanilamide reagent were added, mixed, and proceeded as first step. Standard curve is straight line to $1 \mu \mathrm{g} / \mathrm{ml} \mathrm{NaNO}_{2}$ in final solution.

\subsection{Determination of Sodium chloride \%} (AOAC, 2016):

To 1 gram of the sample, $40 \mathrm{ml}$ of Silver nitrate solution N/10 were added to precipitate all the chloride as Silver chloride, then $5 \mathrm{ml}$ nitric acid was added. The contents were then gently boiled on hot plate until all solids except Silver chloride were dissolved (about 15 minutes). After cooling, $50 \mathrm{ml}$ of distilled water and $2 \mathrm{ml}$ of saturated solution of ferric Ammonium sulphate were added. The excess of silver nitrate was titrated against N/10 Ammonium thiocynate solution using ferric indicator. The amount of standard Ammonium thiocyanate exhausted in the titration (R) was recorded.

The same technique was repeated using 0.5 $\mathrm{ml}$ of the brine solution. The Sodium chloride $\%$ was calculated according to the following formula.

Sodium chloride $\%=(\mathrm{R}-10 \times 0.00585 \times 10)$

Where,

$\mathrm{R}=\mathrm{ml}$ of exhausted $0.1 \mathrm{~N}$ silver nitrate. 


\section{RESULTS}

The results recorded in the table (1) revealed that the mean values of nitrite in beef burger, kofta, frankfurter, sausage and luncheon were $46.75 \pm 2.33,52.18 \pm 2.64,59.29 \pm 3.10$, $67.73 \pm 3.48$ and $79.40 \pm 3.52$ respectively .with minimum values of 5.4,12.1, 16.6, 21.3 and 24.5 and maximum values of $100.9,103.5$, 112.4, 119.7 and 136.8 respectively for the above mentioned meat products.

The results recorded in the table (2) revealed the highest acceptable samples was the beef burger $(96.67 \%)$ while the lowest acceptable was luncheon $(73.33 \%)$ according to the (ES 2005).
The results recorded in the table (2) revealed that the mean values of Sodium chloride (\%) in beef burger, kofta, frankfurter, sausage and luncheon were $1.91 \pm 0.28,2.89 \pm 0.41$, $2.75 \pm 0.32, \quad 3.07 \pm 0.37$ and $3.30 \pm 0.39$ respectively, with minimum values of $1.0,2.3$, 2.0, 2.5 and 2.4 and maximum one of $2.7,3.5$, 3.3, 3.6 and 3.9 respectively for the above mentioned meat products.

The results recorded in the table (4) revealed the highest acceptable samples was the frankfurter (90\%) and the sausage was $(90 \%)$ also, while the lowest acceptable samples were the luncheon samples (80\%) according to the (ES 2005)

Table 1: Statistical analysis of nitrite contents (ppm) in the examined samples of locally manufactured meat products $(n=30)$.

\begin{tabular}{lccccc}
\hline \multirow{2}{*}{ Meat products } & \multicolumn{2}{l}{ +ve samples } & & \\
& No & $\%$ & Min & Max & Mean \pm S.E $^{*}$ \\
\hline Beef burger & 19 & 63.3 & 5.4 & 100.9 & $46.75 \pm 2.33$ \\
Kofta & 22 & 73.3 & 12.1 & 103.5 & $52.18 \pm 2.64$ \\
Frankfurter & 26 & 86.7 & 16.6 & 112.4 & $59.29 \pm 3.10$ \\
Sausage & 27 & 90 & 21.3 & 119.7 & $67.73 \pm 3.48$ \\
Luncheon & 30 & 100 & 24.5 & 136.8 & $79.40 \pm 3.52$ \\
\end{tabular}

Table 2: Acceptability of the examined locally manufactured meat products according to their contents of nitrite $(n=30)$.

\begin{tabular}{|c|c|c|c|c|c|}
\hline \multirow{2}{*}{ Meat Products } & \multirow{2}{*}{ Nitrite (ppm) } & \multicolumn{2}{|c|}{ Accepted samples } & \multicolumn{2}{|c|}{ Unaccepted samples } \\
\hline & & No. & $\%$ & No. & $\%$ \\
\hline Beef burger & $<100$ & 29 & 96.67 & 1 & 3.33 \\
\hline Kofta & $<100$ & 28 & 93.33 & 2 & 6.67 \\
\hline Frankfurter & $<100$ & 26 & 86.67 & 4 & 13.33 \\
\hline Sausage & $<100$ & 23 & 76.67 & 7 & 23.33 \\
\hline Luncheon & $<100$ & 22 & 73.33 & 8 & 26.67 \\
\hline
\end{tabular}


Table 3: Statistical analysis of sodium chloride (\%) in the examined samples of locally manufactured meat products $(n=30)$.

\begin{tabular}{llll}
\hline Meat products & Min & Max & Mean \pm S.E* \\
\hline Beef burger & 1.0 & 2.7 & $1.91 \pm 0.28$ \\
Kofta & 2.3 & 3.5 & $2.89 \pm 0.41$ \\
Frankfurter & 2.0 & 3.3 & $2.75 \pm 0.32$ \\
Sausage & 2.5 & 3.6 & $3.07 \pm 0.37$ \\
Luncheon & 2.4 & 3.9 & $3.30 \pm 0.39$ \\
\end{tabular}

Table 4: Acceptability of the examined locally manufactured meat products according to their contents of sodium chloride $(n=30)$.

\begin{tabular}{llllll}
\hline \multirow{2}{*}{ Meat Products } & $\mathrm{NaCl}$ & $(\%)$ & \multicolumn{2}{c}{ Accepted samples } & \multicolumn{2}{c}{ Unaccepted samples } \\
& & No. & $\%$ & No. & $\%$ \\
\hline Beef burger & $<2 \%$ & 26 & 86.67 & 4 & 13.33 \\
Kofta & $<3 \%$ & 25 & 83.33 & 5 & 16.67 \\
Frankfurter & $<3 \%$ & 27 & 90 & 3 & 10 \\
Sausage & $<3 \%$ & 27 & 90 & 3 & 10 \\
Luncheon & $<3 \%$ & 24 & 80 & 6 & 20 \\
\hline
\end{tabular}

S.E $E^{*}=$ standard error of mean

*Egyptian Organization for Standardization "EOS" (2005).

No 1688-2005 for beef burger

No 3492-2005 for frankfurter

No 1114-2005 for luncheon

\section{DISCUSSION}

The function of nitrite and nitrate in meat is providing three desirable properties to meat to which it is added. First, it fixes the red to pink color, commonly associated with nitrite cured meat, it accomplishes this by combining with haem protein and myoglobin which after heat
No 1973-2005 for kofta

No 1972-2005 for sausage

denaturation becomes relatively stable. Secondary nitrite enhances flavor, i.e. retards its degradation through inhibition by oxidation. The third function is to inhibit toxin production by Clostridium botulinum. So for this functions meat processors insist to use nitrite so far no alternative is available (Gray et al., 1981). 
In this respect Nayel (2013) recorded that mean values of nitrite was 94.75 for beef burger, 79 for kofta, 127 for sausage and 98.65 for luncheon,Vuida-Martos, et al., (2009) who recorded 45.5 \pm 4.3 for luncheon and ELKhawas, (1996) said that $97.255 \pm 12.66$ for luncheon (canned meat). These results were more or less inaccordance with that in the present research . Higher results for luncheon were obtained by EL- Kewaiey and AlTeddawy, (2012), Tolba, et al., (1994) and

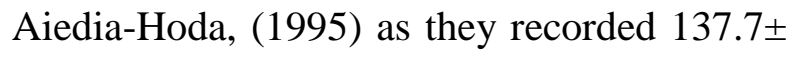
8.05, 118.9 and 134.7 $\pm 2.4 \mathrm{ppm}$. Moreover Ahmad, (2004) recorded higher results for sausage and luncheon where the mean values of nitrite were $120.40 \pm 7.03$ for sausage and $159.96 \pm 6.73$ for luncheon Lower results were obtained by Farag and Abd-El-fatah, (2011) as they could detect nitrite with $24.31 \mathrm{ppm}$ as minimum and 36.71 as maximum for meat products. Slightly lower results obtained by Zahran and Kassem, (2011) for the examined samples of luncheon and sausage.

Sodium chloride reported that sodium chloride has three functions in meat products, first providing and enhancing flavors, second solubilizing protein to create desired texture and third controlling microbial growth to prolong shelf and inhibit pathogens (Terrel, 1983).

Regarding to the obtained data for beef burger, nearly similar results was obtained by Tolba et al. (1994) while higher results were obtained by Mousa et al.(1993), El-Zahaby-Dina (2013) and Nayel (2013) the obtained data for sausage and luncheon were nearly similar to the results obtained by Aiedia-Hoda (1995), Abu-zid Souzan (1998), Nayel (2013) and El-ZahabyDina (2013), while high results obtained by Ahmed (2004).

Although salt added to meat products serve for many functions, but excess use of $\mathrm{NaCl}$ has undesirable effects on the flavor, color and appearance of meat (Pearson and Gillett, 1999) in addition to excessive intake of $\mathrm{NaCl}$ has been linked to serious cardiovascular diseases (Stollewerk et al., 2012).

\section{Conclusion}

The obtained results concluded that some of the meat products included in this study contain residual nitrite and Sodium chloride more than the permissible limits which lead to adverse effect on human public health. So more observation, examination and strict hygienic measure as well as good manufacturing practices (GMP) should be applied for meat products especially when food additives are needed.

\section{REFERENCES}

Abu-Zid, Souzan, M. A. (1998): Anaerobes in meat and fish products and their ability to toxin production. Ph.D. Thesis, Meat Hygiene Fac. of Vet. Med., Cairo Univ.

Ahmed, A. F. (2004): Studies on cooked meat and chicken products. Ph.D. Thesis, Fac. Vet. Med., Zagazig Univ. Benha Branch.

Aiedia-Hoda, A. M. (1995): Quality investigation into room kept traditional meat products in Egypt. Ph.D. Thesis, Fac. Vet. Med. Cairo Univ.

Association of Official Analytical Chemists "AOAC" (2005): Official methods of analysis. 14 ${ }^{\text {th }}$ Ed., W. Horwitz .w, (Editor), Academic Press, Washington, D.C., USA.

Association of Official Analytical Chemists "AOAC" (2016): Official methods of analysis. $17^{\text {th }}$ Ed., W. Horwitz .w, (Editor), Academic Press, Washington, D.C., USA. 
Bories, P. N. and Bories, C. (1995): Nitrate determination in biological fluids by enzymatic one-step assay with nitrate reductase. Clin. Chem., 41:904-907

ES 2005: Egyptian Organization for Specification and Quality Control "E .O.S.Q.C." (1991): Egyptian standard for requirements of corned beef, Ministry of Industry No.1563.

ES 2005: Egyptian Organization for Specification and Quality Control "E .O.S.Q.C." (1991): Egyptian standard for requirement of canned luncheon, Ministry of Industry No.1114.

ES 2005: Egyptian Organization for Specification and Quality Control (2005): Egyptian Organization for Specification and Quality Control for beef burger, Ministry of Industry No. $1688 / 2005$.

ES 2005: Egyptian Organization for Specification and Quality Control (2005): Egyptian Organization for Specification and Quality Control for frankfurter. Ministry of Industry, No. 3492/2005.

ES 2005: Egyptian Organization for Specification and Quality Control (2005): Egyptian Organization for Specification and Quality Control for Luncheon. Ministry of Industry, No. 1114/2005.

ES 2005: Egyptian Organization for Specification and Quality Control (2005): Egyptian Organization for Specification and Quality Control for Sausage. Ministry of Industry, No. 1972/2005.

El-Kewaiey, I. A. and Al-Tedawy, F. A. (2012): Determination of sodium nitrite in some locally manufactured meat products. Assiut Vet. Med. J., 58(132): 159-174.

El-Khawas, K. M. S. (1996): Public health aspects of canned meat. M.V.Sc. Thesis, Fac. Vet. Med. Zagazig Univ.

EL-Zahaby, D. I. (2013): Chemical evaluation of some food additives in meat products. Ph. D. V.Sc. Thesis, (Meat Hygiene). Fac. Vet. Med., Benha Univ.

Farag, H. El-S. M. and Abd-El-Fatah -Noha, R. M. (2011): Assessment of Nitrite and Sorbic acid salts level in some meat products and their public health significance. Assiut Vet. Med. J. 57(129): 1-22.

Gray, J. I., Macdonald, B., Pearson, A.M. and Morton, I.D. (1981): Role of nitrite in cured meat flavor: A review J. Food protect., 44:302.

Mousa, M., Samaha, L. and Edris, A. (1993): Studies on chemical analysis of samples of beef burger, hot dog, kofta, minced meat, pasterma and sausage. Alex. J. Vet. Sci., 9: 123-125.

Nayel, M. S. (2013): Studies on chemical preservatives in meat products. Ph. D. V.Sc. Thesis, (Meat Hygiene). Fac. Vet. Med., Benha Univ.

Ripolles, S., Campagnol, P. C., Armenteros, M., Aristoy, M. C. and Toldra, F. (2011): Influence of partial replacement of $\mathrm{Nacl}$ with $\mathrm{Kcl}, \mathrm{Cacl}_{2}$ and $\mathrm{Mgcl}_{2}$ on lipolysis and lipid oxidation in drycured ham. Meat Science, 89(1):58-64.

Sindelar J.,(2012) University of Wisconsin Meat Laboratory, Meat Science \& Muscle Biology Lab, 1805 Linden Drive, Madison, WI 53706. 
Stollewerk, K., Jofre, A. Comaposada, J. Arnau, J. and Gerriga, M. (2012): The effect of Nacl. Free processing and high pressure on the fate of Listeria monocytogens and Salmonella on sliced smoked dry-cured ham. Meat Sci., 90(2): 472-477.

Taormina, P. J. (2010): Implications of salt and sodium reduction on microbial food safety. Critical Reviews in Food Science and Nutrition, 50(3):209-227.

Terrell, R. N. (1983): Reducing the sodium content of processed meats. Food Technol., 37:66.

Tolba, K.S.; Abdel-Aziz, A.S. and NiaziZeinab. (1994): Chemical analysis of locally manufactured meat products. Vet. Med. J., 42: 79.

Viuda-Martos, M.; Fernández-López, J.; Sayas-Barbera, E.; Sendra, E.; Navarro, C. and Pérez-Alvarez, J. A. (2009): Citrus co-products as technological strategy to reduce residual nitrite content in meat products. Journal of Food Science, 74(8):R93-R100.

Zahran- Dalia, A. and Kassem- Gehan, M. A. (2011): Residual nitrite in some Egyptian meat products and the reduction beam irradiation. Advance $\mathrm{J}$. Of Food Science and Technology, 3(5): 376-370. 